\title{
開発設計技術における課題と提言
}

\section{中沢 弘**}

Problems and Proposals of Develooment Design Technology /

HirOmU NAKAZAWA

Key words: development, design, design process, design navigation method,

conceptualization, embodiment design

\section{1.は じめに}

1999 年 1 月号の巻頭言で古川勇二会長が大変重要な指 摘を幾つかされている. その一つに「わが国は製造工程の 革新から製品技術の革新に移行しなければならない」とい われている. 私も全く同感である.

現在この関連で組織だって行われている研究は日本学術 振興会の未来開拓学術研究推進事業の一つとしての「シン セシスの科学」が唯一のものではないだろらか. このプロ ジェクトは 4 つのサブテーマに分れて行われている.

（1）人間指向シンセシスの科学：代表早稲田大学 中沢弘

（2）シンセシスのモデル論：代表東京大学 冨山哲男

（3）創発的シンセシスの方法論：代表神戸大学 上田完次

（4）人工知能による協調的シンセシスの方法論：代表大阪 大学 溝口理一郎

これらの研究は 2000 年度に完了するので（(4) は 2001 年度に完了), その全成果はその時点で公開されるであろ 亏.

\section{2. 開発設計の現状と問題点}

上記のプロジェクト研究の一環として設計過程の分析に 関するアンケート調査を行ったことがある. 調査対象は日 本機械学会技術賞を受賞した技術者扣よびそれ以外の一般

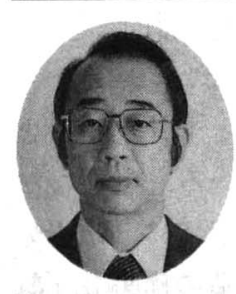

* 原稿受付 平成 11 年 10 月 8 日

** 正 会 員 早稲田大学理工学部（東京都新宿区 大久保 3-4-1) 1961 年早稲田大学第一理工学部機械工学科卒, 同年新三菱重工入社. 1972 年早稲田大学理工 学部助手, 専任講師, 助教授を経て 1982 年同 教授, 現在に至る. 工学博士 (早稲田大学). 研究分野：人間中心生産システム, シンセシス 工学
的な技術者である. 設計項目（内容を表 1 に示す）の相関 を優秀な設計者の場合を図 1 に, 一般の設計者の場合を図 2 に示す. 詳しい内容は文献を参照して頂きたいが1)，両 者の主な違いをまとめると次の通りである.

(1) 優秀な設計者は開発設計を「文献調査 (シーズ)」

表 1 設計項目の説明

\begin{tabular}{|c|c|}
\hline 市場分析 & $\begin{array}{l}\text { 市場や自社からの情報により市場を分析し, 会社の } \\
\text { 潜在能力と目的を明確にする. }\end{array}$ \\
\hline 抽象化 & $\begin{array}{l}\text { 特殊なものや付帯的なものを無視し, 一般的で本質 } \\
\text { 的なものを強調する行為である. }\end{array}$ \\
\hline 機能設定 & $\begin{array}{l}\text { 適切な入力と出力を含めた要求機能㧍よび制約を, } \\
\text { 作業開始時に正しく規定する. }\end{array}$ \\
\hline 機能構造 & 複雑な全体機能をより単純な下位構造に分解する. \\
\hline 文献調査 & $\begin{array}{l}\text { 最新の技術データを載せた技術雑誌や特許資料など } \\
\text { を調査する. }\end{array}$ \\
\hline 分 析 & $\begin{array}{l}\text { 自然界の形態, 構造, 組織, プロセス, 既存の技術 } \\
\text { システムを分析する. }\end{array}$ \\
\hline 試 験 & $\begin{array}{l}\text { 設計解に到達するための既存システムの測定やその } \\
\text { 他の実験的研究. }\end{array}$ \\
\hline 発想行為 & 新しいアイデアや問題の解決案を発想する行為. \\
\hline 物理解析 & $\begin{array}{l}\text { 問題の設計解を解析することによって新規または改 } \\
\text { 善された解を得る. }\end{array}$ \\
\hline カタログ & 設計カタログや分類表を使用し設計解を模索する. \\
\hline 選 択 & 豊富な提案の中から有望な設計解を模索する. \\
\hline 評 価 & 提案を決定するため経済的基準による評価を行う. \\
\hline 経験的改善 & 自己の知識経験を基に直感的な改善を行ら。 \\
\hline レイアウト & $\begin{array}{l}\text { 様々な要因を考慮しながら機能要素のレイアウト設 } \\
\text { 計を行ら. }\end{array}$ \\
\hline 形態設計 & $\begin{array}{l}\text { 様々な要因を考慮しながら構成部材の形状と材料を } \\
\text { 決定する. }\end{array}$ \\
\hline 製造工程 & $\begin{array}{l}\text { 部品の構造, 組立, 工作機械の人員の配置などの決 } \\
\text { 定をする. }\end{array}$ \\
\hline
\end{tabular}




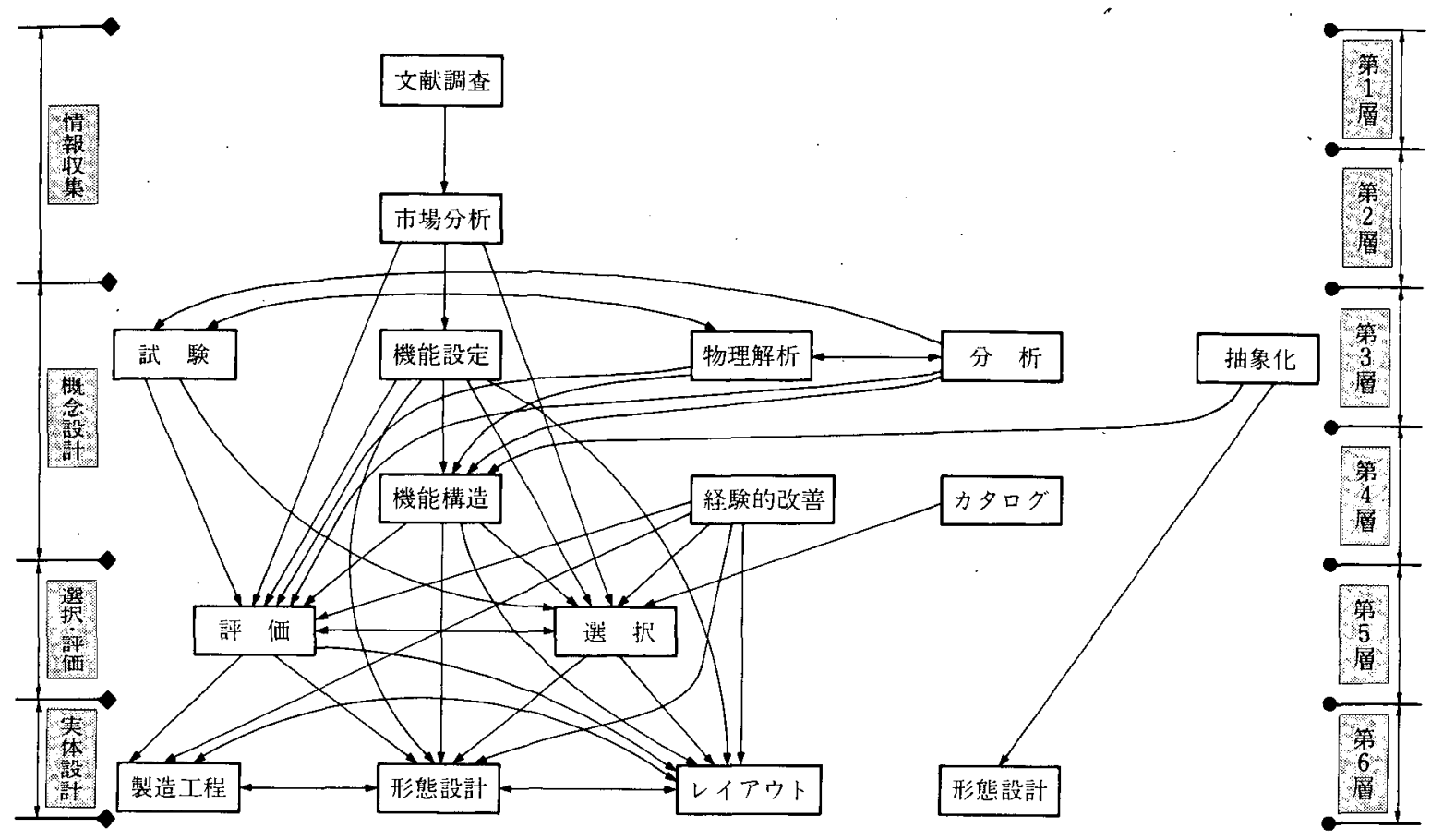

図 1 優れた設計者の設計工程
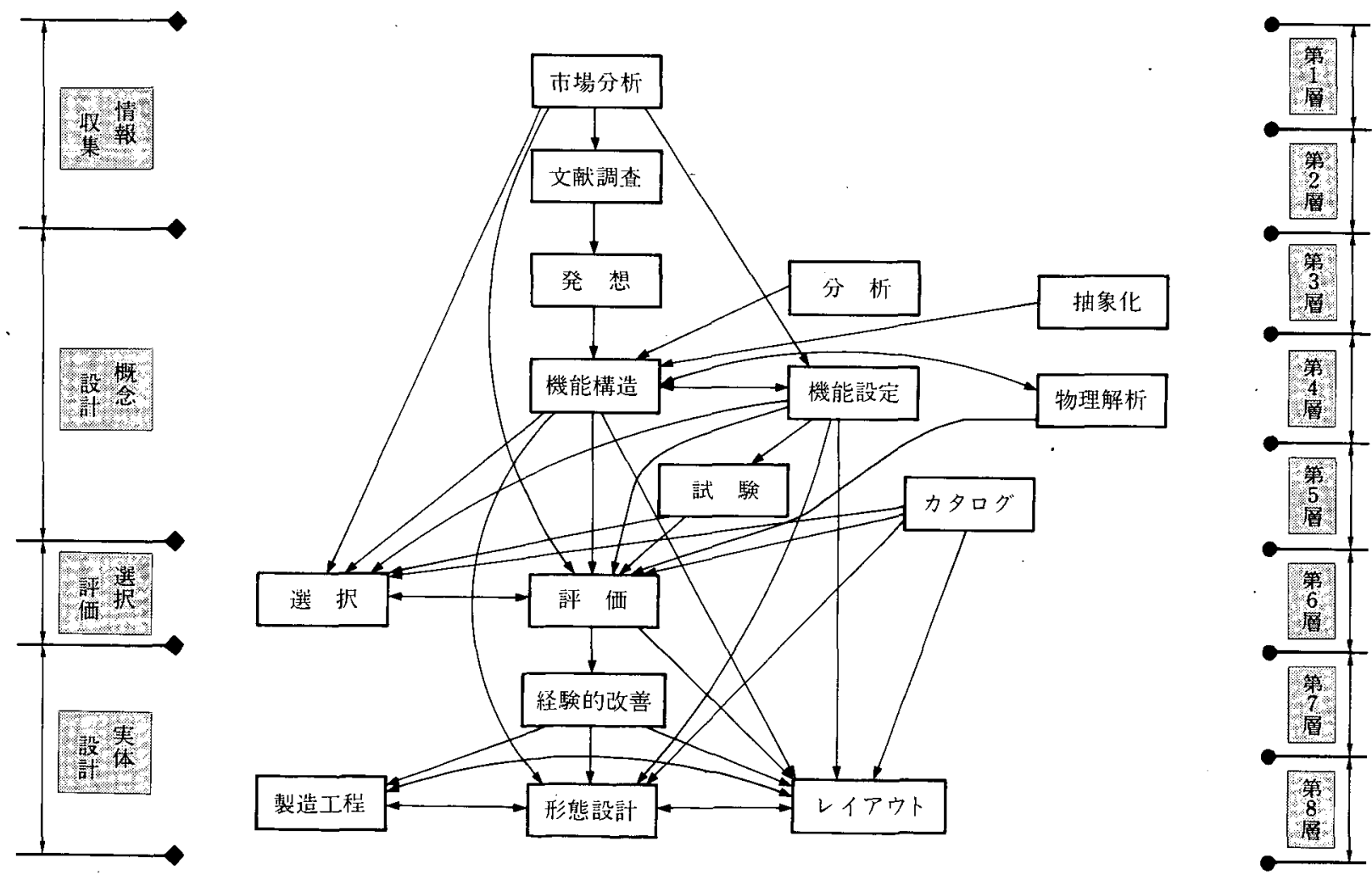

図 2 一般設計者の設計工程

から始めるが一般の設計者は「市場分析・動向調查 (ニーズ)」から始めている.

(2) 優秀な設計者は「機能設定」を行ってから「機能構 造の構築」を行らが，一般の設計者は「機能構造の 構築」と「機能設定」を同時的に行っている.

(3) 優秀な設計者では「経験に基づく直観的改善」が 「評価」，「選択」，「製造工程の決定」，「形態設計」，
「レイアゥト設計」に影響を与充ているが，一般の 設計者では「製造工程の決定」，「形態設計」，「レイ アウト設計」にしか影響を与えていない.

(4)重要な決定をする設計項目は両者とも「選択」と 「評価」の項目と閉じた系を作っている．重要な決 定をする設計項目とは，優秀な設計者では「市場分 析・動问調查」,「抽象化」,「機能構造の構築」,「試 
験・計測」「経験に基づく直観的改善」の 5 つが, また一般の設計者では最後の「経験に基づく直観的 改善」を除く4つが含まれる。

(1)に関しては，レベルの高い開発（日本機械学会技術 賞を受賞するような開発）を行うにはやはりシーズから 入っていくべきであろら。また, 後戻りのない確実な仕事 をするためには先に機能的要求を明確に設定しておくべき である(2)).しかし，この調査でも設計技術を身につけ るのは経験が大切であることが分かる（3),(4)）.

ここで開発設計技術をどこまで教育で身に付けさせられ るかといらことがひとつの問題提起である.ささらに一般の 設計者，特に若い設計者が高い生産性で良い設計がでさる よらに支援するにはどうしたらいいかといらことが次の問 題である.これらの問題について筆者らは現在研究中であ クまだ提言できるところまでいっていない。

設計プロセスはいずれのカテゴリーの技術者に対しても 基本的に図 1,2 に示すように情報收集，概念設計，選択・ 評価, 実体設計の 4 つのフェーズに束とめられる. 以下こ のプロセスを基に話を進める.

情報収集プロセスでは開発テーマの発見法が問題にな る.これにはニーズから見つける，シーズから見つける， ビショョンから考觉るの 3 通りがあるが，紙面の都合で詳細 な説明は省略する.

\section{3. 概念設計と選択 - 評価：抽象化}

概念設計と選択・評価のフェーズで重要なのは抽象化と いうプロセスである. どのレベルの仕様（ニーズ）が与え られるかによるが，それから直ぐに仕事を始めるのではな く，その本当の使命は何かといらことを分析して上位の概 念（機能的要求）に戻ることが必要である. これを筆者は 「メタコンセプトの原理」と呼んでいる.これはニーズか ら開発テーマを見つける際にマスクドニード2をを見い出す ことか゚重要であるといらこととも関連する。ここでいらメ タコンセプトの原理はいろいろな問題に適用できる.

例えば自動車のワイパは，どしゃ降りになると前方がほ とんど見えなくなり困った経験を持らの持い多い思 5.ここで普通は，どしゃ降りでも前方が見えるワイパを 作ろらと考えて, ブレードの形状を変えたり, 動くスピー ドを変えたりする改良設計に走る.しかし，メタコンセプ トの原理はそうではなく，この場合の本当の使命（要求） は何かを考皇なさいといらことを要求しているのである. ワイパに要求される機能 (使命) は，どんな雨が降っても 前方の状態がある程度確認できれば良いのである.という ことが分かるとブレード形状を变えるだけでなく他のいる いろなアイデアが出てくる.コストの条件を外すと，例亲 ば，レーダを付ける，路面に埋め込んだ電線で電磁誘導す る……どが出てくる. (i) 交換・逆転; 原因と結果

$$
\text { 入力と出力 }
$$

動力端と作業端

（2）直列と並列との入れ替え

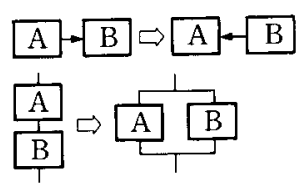

(3) 四則 ;

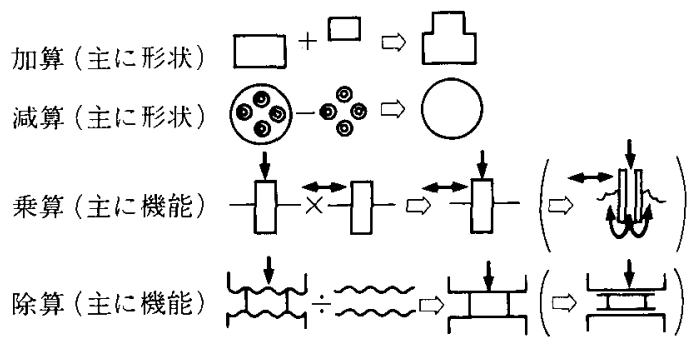

(4) 写像 $(1 / z$ 写像 $)$; 内部と外部の入れ替之

（5）对称・鏡像・回転;

(6) 相似則;

（7）拡大・繀小; 全体, 部分

（8）変形; 機能の関連不変 形状のみ連続変化
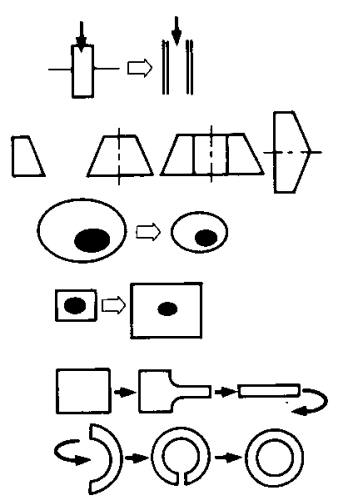

图 3 着想を発展させるための思考演算

\section{4. 実体設計：構造設計と発想法}

テーマが見つかり, 機能的要求, 機能構造の決定までは 一般の設計者でもある程度まで容易にできる.しかし，そ の次のステップの構造設計・実体設計（レイアウト設計と 形態設計を含む）が一般に問題となる。このプロセスは一 般の設計者のみならず優秀な設計者でも苦しむところであ る.ここでは設計者の発想力がものをいら．この発想を助 けるために従来いろいろな発想法が提案されてきた.ブ レーンストーミング(これもいろいろな改良型がある), $\mathrm{KJ}$ 法, NM 法, シネクティクス等々がある.これらはそ れぞれ得意とする適用分野があり，それなりの成果を出し ているが構造設計にはあまり助けにならない.

最近注目されているのが TRIZ(「発明問題解決の理論」 というロシア語の頭文字を取ったもの）である゙๋.この TRIZ は約 50 年前に旧ソビェト連邦で開発が始まり，発 達してきたものである。斬が崩壊するまでは国家プロ ジェクトとして世界中の約 250 万件の特許を調べて，新し い発明を考えていくのにどんな法則性があるかが徹底的に 検討された．このソフトは日本でも販売されている.これ を使えば大発明ができるという訳ではないが，それなりの 効果はあるようである.

めっと簡単に発想できるような万法やシステムが求めら れている，その中で注目を集めているのが烟村が提案して いる思考演算 ${ }^{3)}$ である. 概略を図 3 に示す．この方法は, 
例之ば原因と結果，または入力と出力を入れ替光る「交 換・逆転法」, 数学の「四則」と同じょうに形状についての 「加算」と「減算」機能や作用についての「乗算」と「除 算」, 境界の内部之外部を入れ替える $\lceil 1 / z$ 写像」,「対 称・鏡像・回転」，トポロジー的変形の「相似則」，「拡大・ 縮小」「変形」なぞがある。残念ながらこれ以上の詳しい 解説は発表されていないが，この図だけからでもかなり有 益な発想法のヒントが得られる。

いずれも使いこなすまでにはある程度の忍耐と努力が要 る。したがって自分に合った手法を見つけ，それを自分な りに修正改良して使いこなすすとが設計者に求められてい る.ささらに発想法だけでは優秀な設計者, 熟練設計者のも つ経験と知識に対応することは無理であろう。この点に関 して経験の浅い設計者がより良い設計のできるように何ら かの支援システムの開発が望をれる。

\section{5. 実体設計：デザイン・ナビゲーション・ メソッド}

ここまで開発のプロセスが進んでくると後は簡単と言え ればいいのであるが，しかし実体設計となるとそうは簡単 にはいかない，現果にはトラ.イアル・アンド・ェラーを繰 り返してなかなか最適設計ができないのが現状である う.この原因としては一つには開発設計という，ある意味 では経験のない新しい分野で，したがって理論計算もでき ないといら条件のもとで，最初から最適な設計をしろとい ら方が無理といらすのである．やはり新しいことをする場 合は実験と平行して行らのが合理的である。しかし，あら ゆる条件で網羅的に実験をやるわけにるいかず，また要求 項目間にトレードオフがある場合には，得られた実験值か ら最適な設計パラメータを決めることさえる困難をきた す.

ここではそのよらな場合に役立つデザイン・ナビダー ション・メソッド（中沢メンッド）といら筆者が開発した 手法を紹介（提言）したい。これはまだ公の論文としては どこにも発表していないが，すでに 16 社の企業がこれを 導入乙，鍼负針の加工法の確立，歯科用ハンドピース チャック，光サーキュレータ素子などの新規開発，スク ロールポンプ, 電子機器用冷却ファン, 電子部品コネク タ, 生産条件の改善などの改良的開発で央際に大きな成果 を挙げている.

\section{1 実験の計画}

まず実体設計の計画図ができた段階で，性能上重要だと 思われ，しかもどのよらに最適值を決めるか分からないと いら設計パラメータを複数選定する。設計パラメータとし ては寸法, 公差, 材料, 熱処理硬度, 運転条件（例之ば回 転数, 加熱温度, 然料供給量…) などのようなものでもよ い. パラメータの数もとくに制限はないが，その数によっ
表 $2 \quad L_{9}$ 直交表

\begin{tabular}{|c|c|c|c|c|c|c|c|}
\hline & \multicolumn{4}{|c|}{ 設計パラメータ } & \multicolumn{3}{|c|}{$\begin{array}{l}\text { 評洒項目に対する } \\
\text { 罢験データ }\end{array}$} \\
\hline & $A$ & $B$ & C & $D$ & $E$ & $F$ & $G$ \\
\hline 1 & $A 1$ & $B 1$ & $\mathrm{Cl}$ & $D 1$ & $x 1$ & $y 1$ & $z 1$ \\
\hline 2 & $A 1$ & $B 2$ & $C 2$ & $D 2$ & $x 2$ & $y 2$ & $z 2$ \\
\hline 3 & $A 1$ & B3 & $\mathrm{C} 3$ & $D 3$ & $x 3$ & $y 3$ & $z 3$ \\
\hline 4 & $A 2$ & $B 1$ & $C 2$ & D3 & $x 4$ & $y 4$ & $z 4$ \\
\hline 5 & $A 2$ & $B 2$ & C3 & $D 1$ & $x 5$ & $y 5$ & $z 5$ \\
\hline 6 & $A 2$ & $B 3$ & $C 1$ & $D 2$ & $x 6$ & $y 6$ & $z 6$ \\
\hline 7 & $A 3$ & $B 1$ & $C 3$ & $D 2$ & $x 7$ & $y 7$ & $z 7$ \\
\hline 8 & $A 3$ & $B 2$ & $C 2$ & $D 3$ & $x 8$ & $y 8$ & $z 8$ \\
\hline 9 & $A 3$ & $B 3$ & $C 1$ & $D 1$ & $x 9$ & $y 9$ & $z 9$ \\
\hline
\end{tabular}

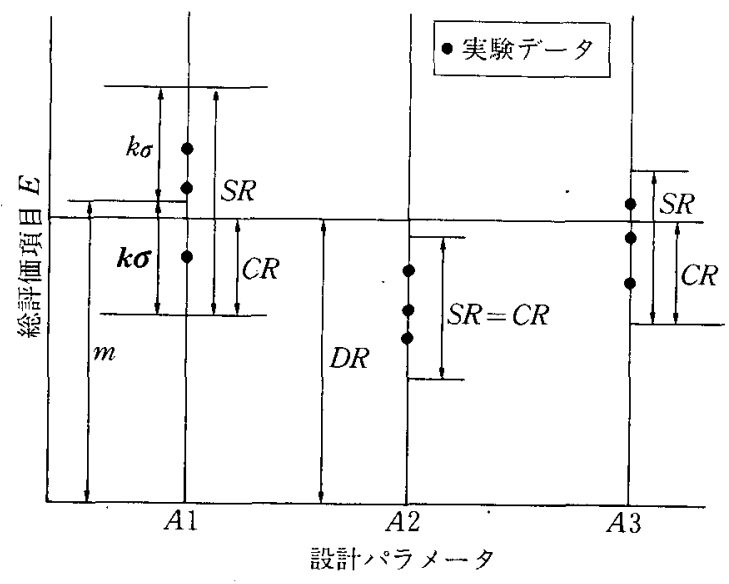

図 4 設計パラメータと実験データ

て実験の回数が変わってくる。一般に実験回数はできるだ け少なく済ませたい，そこで㬰験計画法の直交表を使って 実験条件の水準をうまく組み合わせてできるだけ少ない実 験から情報を得ることにする，したがって直交表に合わせ たパラメータの数が望ましい，例えば $L_{9}$ の直交表を使用 する場合，最大 4 つの設計パラメータが設定できる，表 2 の $A \sim D$ がそれである.これらをそれぞれ 3 水準に振っ て表の組合せで製品（または条件）を作り実験する。

実験は，最初に決めた機能的要求に対応した評価項目に 対してデータを採る（表の例では $E, F, G$ に対応）。実験 は当然のことながら，実際にその製品が使用される条件と 同じ条件で行らことが大切である．全部の実験が終わると 表 2 の例では，設計パラメータの各水準に対して 3 個ずつ のデータが得られる．もちろん外部実験条件を变えて，各 組合せに対して複数回実験してもよい，その場合はデータ 数は 3 個以上になる．それを設計パラメータ $A$ に対して 図示すると図4のようになったとする. 図中のデザインレ ンジ $D R$ とは性能がこうあって欲しいという範囲で,で きるだけ合理的に，厳密に決められなければいけない，本 図の場合は值の小さい方が良いという例であるが，もちろ ん值が大きい方が好ましいという場合は上側に取ることに なる. 


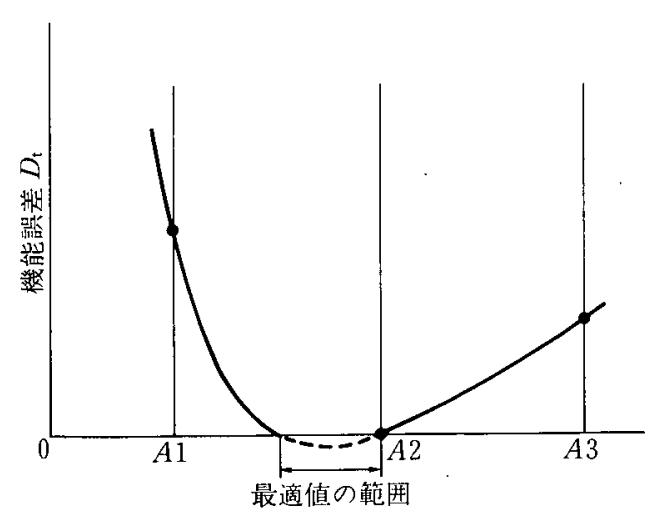

图 5 設計パラメータの最商值

\section{2 実験データの解析}

上の例で各水準に括ける 3 つのデータ（例えば $A 1$ の位 置で評価項目 $E$ については $x 1, x 2, x 3$ のデータがある) から平均値 $m$ と標準偏差 $\sigma$ を求める.

$m \pm k \sigma$

をシステムレンジの上限と下限と定義する． $k$ は安全率と する.データのばらつく範囲はこの標準偏差で予測される 範囲より広い範囲にばらつく可能性があるからである．今 までの経験上 $k=1.5$ がよいよらである。これとデザイン レンジ $D R$ の重なる部分をコモンレンジと定義する．図 の例でい点ば $S R$ がシステムレンジであり， $C R$ がコモン レンジである.

この 2 つの量から機能誤差 $D$ を次のように定義する.

$$
D=\ln \frac{S R}{C R}
$$

これは情報積算法 ${ }^{4) 5}$ の情報量に対応する.ここでは データ（性能）のばらつく範围・(システムレンジ) がデザ インレンジからどれくらい食い違っているか，つ毛り目標 としている機能からこの実験条件での機能がぞれくらい外 れているかを示す. システムレンジが完全にデザインレン ジに入ってしまうと， $S R$ とRが同じ值となり機能誤差 $D$ はゼ口となり, 完全に機能的要求を満足していること になる．完全にシステムレンジがデザインレンジから外れ てしまうと $D$ は無限大となってしまう。

このようにして $A 1$ の位置に対する機能誤差 $D$ を他の 評価項目 $F, G$ についても求め, それらを合計する. 合計 した機能誤差を $D_{\mathrm{t}}$ とし総機能愦差と呼ぶとすると, 各評 価項目に対する機能誤差を上の例では $D_{\mathrm{e}}, D_{\mathrm{f}}, D_{\mathrm{g}}$ として,

$$
D_{\mathrm{t}}=D_{\mathrm{e}}+D_{\mathrm{f}}+D_{\mathrm{g}}
$$

となる.この総機能誤差に関して次の公理を提案する.

公理「総機能誤差が小さいシステムほどよいシステムで ある」

ここで言らシステムとは開発する製品・技術はるとより運 転条件などむ含まれる．これは情報積算法で言ら総情報量 公理と本質的に同じである.

この総機能誤差を $A 2, A 3$ についても求め, 図 5 のよう
にプロットする.これらの点を通る曲線を 2 次曲線で近似 して, 総機能誤差が最小になる点を求めると, それが設計 パラメータAの最適值になる.この例の場合は設計パラ ィータの値がある範用で機能誤差がゼ口となっている.し たがってAの最適值としてはゼ口の値の範囲の中の適当 な值（例えば中間の値）を採用すればよい。他の設計パラ メータ $B, C, D$ Kついても同様に求められる.

この場合各設計パラメータをこのように独立に求められ るのかといら嫙問が湧くが，最適值を求めた設計パラメー 夕值に対応する機能䛊差がゼロである限り, 性能のばらつ く範团，つまりシステムレンジはある安全率 $k$ を持って 必ずデザインレンジの中に完全に含まれているので，他の 設計パラメータがどのように変兄られようと問題はない. ただし，もしも最適值の所の機能䛊差がゼ口でなくある值 を持っている場合，そのシステム゙レンジの外れている割合 だけ他の設計パラメータの選び方によっては性能がデザイ ンレンジから外れる確率が高くなってくる.したがってあ まり機能誤差が大さい時は問題が生じる可能性があるので 基本設計を変えなければならない。

さてこれで最適值がすべて決まったら，最後にこれらの 最適值の組合せで製品を作り，性能破認実験を行う。これ で一連の作業は終了する．以上にデザイン・ナビゲーショ ン・メンッドの概略を示したが，多少のノウハウがいると はいえ，これだけの情報でも十分に使えるので興味のある 方は試しに使って頂きたい，今まで使った限りではうまく いかなかった例は一度もなかった。

\section{6. おわ $わ に$}

日本は今までは「外国の先進技術の後追いをしてきて飯 が食光たが，今は自ら開発の先頭に立たなければならな い」，とはよく言われることである. その意味でも我々は すで確立されている，新しい開発設計技術をマスターし て世界をリードする責任があることは当然であるが，それ 以上にい季だ山積している開発設計技術の䛺題を研究して 解決していかなければならない責任があると考光る.

最後にデザイン・ナビゲーション・メンッドの研究に日 本学術振興財団の研究費の支援を頂いたことをここに明記 して感謝する。

\section{参 考 文 献}

1）中沢 弘，松永久，清水良樹：人間の設計過程のモデル化 に関する研究（第 1 報・優れた設計者の設計過程の分析），日 本機械学会論文集 (C 編)，65, 631 (1999) 410.

2）糸川英夫：前例がないからやってみよう，光文社カッパプッ $\eta$ ス, (1997).

3）烟村洋太郎, V. R. Fey, E. I. Rivin：TRIZ 入門，日刊工業新 聞社, (1997).

4）中沢 弘：情報樍算法, コロナ社, (1987).

5）中沢 弘：技能者の満足感を定量評価，簡単な評価法の情報 耫算法, 日経メカニカル, 10 月 18 日号, 40/51 (1993). 